\title{
A GRANDE TRANSFORMAÇÃO AMBIENTAL - UMA CRONOLOGIA DA DIALÉTICA HOMEM-NATUREZA
}

por José Augusto Drummond*

BURSZTYN, Marcel; PERSEGONA, Marcelo. A grande transformação ambiental: uma cronologia da dialética homemnatureza. Rio de Janeiro: Garamond, 2008. 405 p.

A maneira como o livro foi concebido e executado lhe dá um enorme potencial de uso e de repercussão. É uma obra de referência, contendo breves verbetes sobre fatos, processos, entidades e personalidades ligados à emergência da moderna questão ambiental, dispostos em ordem cronológica. Os verbetes são acompanhados de referências (livros, portais, etc.), nas quais os interessados podem buscar mais informações. Mesmo para cidadãos e profissionais escolados na questão ambiental, o volume deve estar à mão em uma prateleira próxima, para tirar dúvidas, fazer conexões, fornecer lugares, datas e nomes precisos de pessoas e instituições. Para os iniciantes, ele deve constar entre as obras de referências das bibliotecas públicas.

Não se trata, porém, de uma enciclopédia sobre o vasto universo da questão ambiental, cuja amplitude e complexidade são suficientes para preencher vários volumes. O segredo do sucesso dessa cronologia se chama "seleção". Os temas dos verbetes foram selecionados em função da combinação de dois fatores: (1) a sua

\footnotetext{
* Professor adjunto do Centro de Desenvolvimento Sustentável (CDS) da Universidade de Brasília (UnB).
} 
repercussão (nem sempre imediata) e (2) a sua capacidade de influenciar o futuro, a partir de leituras posteriores. Um critério complementar de seleção foi o foco em temas de amplitude nacional, relevantes ao Brasil. Ainda assim, o leque de assuntos é rico na sua variedade. A seleção dos verbetes garantiu ao volume as virtudes da brevidade, do fácil manuseio e da interconexão de seus componentes.

A espinha dorsal do livro é a "cronologia" propriamente dita, que ocupa mais de 320 páginas ( $80 \%$ do volume). Ela transita rapidamente até os séculos XIV e XV, mas, a partir daí, se torna mais "densa", demorando muito mais a percorrer os séculos seguintes e, mais adiante, as décadas recentes. Isso reflete a atual intensificação dos problemas e da consciência ambientais. A cronologia segue, principalmente, acontecimentos, entidades e pessoas ligados às conseqüências ambientais e sociais da expansão européia dos últimos 500 anos, em particular, a expansão ibérica em terras do Continente Americano. No entanto, quase todas as áreas do planeta e os seus respectivos povos e componentes naturais acabam sendo mencionados na cronologia. Além das referências a textos e portais, cada verbete contém ícones sinalizando os campos temáticos a que ele pertence - (ONGs, população, energia, água, flora, fauna, fogo, clima, etc.). Alguns verbetes merecem ilustrações, como fotografias, desenhos e mapas.

Outras seções ampliam o alcance da cronologia, enriquecendo, sobremaneira, a utilidade do livro e facilitando o seu manuseio. Há seis anexos muito bem organizados - um glossário, uma lista das abreviaturas e siglas usadas, uma lista de organizações ambientalistas, uma cronologia resumida, uma lista de páginas da Internet sobre tratados e acordos relevantes e uma lista dos "grandes impactos" ambientais previstos para o século XXI.

Raridade em livros editados no Brasil, a obra traz, ainda, um valioso índice remissivo (contendo nomes de pessoas, títulos 
de livros e tratados, eventos, etc.). Por exemplo, o índice traz os nomes de cinco dezenas de navios-tanque, plataformas de extração de petróleo e localidades ligadas a grandes derramamentos de petróleo ou afetadas por eles. Outro exemplo é a inclusão de dezenas de tratados, leis e ações reunidos sob a palavra "proteção" (áreas, recursos e espécies animais e vegetais). Ou seja, o índice cumpre bem a função de direcionar consultas tanto para temas bem específicos quanto para outros mais gerais. O livro incorpora ainda uma moderna característica de "obra aberta", pois oferece aos leitores uma página de Internet em que eles podem sugerir a revisão de verbetes e a inclusão de novos verbetes em futuras edições.

O lastro factual deste livro é bastante oportuno. Os tempos atuais estão paradoxalmente difíceis para a questão ambiental. Ela tem, hoje, uma notoriedade insuspeitada, mesmo, há apenas 15 ou 20 anos, mas isso não ocorreu sem custos. Hoje em dia, é difícil encontrar, em qualquer escala geográfica, atores sociais ou políticos que neguem a existência de graves problemas ambientais ou que se proclamem indiferentes a eles. Ao contrário, a questão ambiental transbordou os circuitos relativamente limitados em que nasceu há poucas décadas e se tornou "multissetorial" (na expressão consagrada por Eduardo Viola e Hector Leís). Para o mal ou para o bem, alguns dos mais importantes geradores dos problemas ambientais se declaram, hoje, engajados na sua resolução. Não é incomum que reivindiquem até uma posição de pioneirismo na própria emergência da questão ambiental.

De outro lado, nas fileiras dos próprios ambientalistas "históricos", a identidade da questão ambiental está, igualmente, em erosão. Muitos deles, empolgados com a maior visibilidade da "causa", agora associam ou mesmo subordinam a questão ambiental a imperativos de causas correlatas, mas distintas, como justiça social, combate à pobreza, reordenamento tecnológico ou mesmo a construção de uma nova ordem internacional. Independentemente 
das conexões de fato existentes entre o meio ambiente e essas outras esferas, tal tendência cria uma série de dificuldades na hora de identificar as questões propriamente ambientais e de buscar soluções específicas para elas.

Nesse contexto de banalização da questão ambiental, um livro como A Grande Transformação Ambiental é uma âncora que ajuda a fixar a atenção e a encarar realisticamente as causas, as bases e as conseqüências dos problemas ambientais propriamente ditos. Ele oferece, de forma organizada, as datas, os lugares, as pessoas, as instituições, os fenômenos naturais, os desastres ambientais, as opções de tecnologia, as substâncias tóxicas e os esforços de prevenção e de correção dos problemas ambientais. Permite perceber o tamanho específico da questão ambiental no mundo contemporâneo e avaliar melhor as suas inúmeras conexões com outros temas. Ficam claros, ainda, os atritos e mesmo as incompatibilidades que a questão ambiental inevitavelmente tem com assuntos de outra ordem. Ajuda a evitar percepções simplistas de que o citado caráter "multissetorial" do tema conduza, automaticamente, à sua adoção "transversal" pelos diversos atores, públicos e privados, já que existe entre estes pouco consenso sobre o que seja o problema ambiental e sobre o que deva ser feito em relação a ele.

Percebo a possibilidade de outro papel para este livro, de dimensão muito maior, já que envolve a formação das novas gerações, não apenas o "refinamento" da percepção da geração atual. Seu conteúdo, colocado em outro formato ou outros formatos, pode compor um excelente texto de referência para estudantes do Ensino Fundamental. Não existe, em língua portuguesa, um texto sobre esse tema com tal amplitude de conteúdo e com esse formato de cronologia organizada e fácil de manusear. Ou seja, este livro, recém-lançado, já pede uma reedição na forma de livro paradidático, de grande tiragem, para constar das bibliotecas de milhares de escolas públicas e privadas do Ensino Básico por todo o País. 